\title{
Nigerian Stock Exchange and Weak Form Efficiency
}

\author{
Ogbonna, Udochukwu Godfrey ${ }^{1}$ Ejem, Chukwu Agwu ${ }^{2}$ \\ 1.Department of Management Science, Rhema University, Aba, Nigeria \\ 2.Department of Banking and Finance, Abia State University, Uturu, Nigeria
}

\begin{abstract}
This study, Nigerian Stock Exchange and Weak Form Efficiency with two intervals of All Share Index collected from the Nigeria Stock Market fact books. This study employed various parametric tools found for daily and annual all share index as follows: a significant relationship between the price series and their lagged values; coefficient of variance equations are statistically significant; price series do not follow a random walk or are abnormally distributed; level series not significant and causality is found in daily price series with no causality found in the annual price series. The finding in this study in balance affirmed that the Nigeria Stock Exchange is not efficient in weak form, by extension is inefficient in any form. As result the researchers suggest to the supervisory and regulatory authorities to promulgate laws that will strengthen the Nigerian Stock Market.
\end{abstract}

Keywords: NSE, Weak Form, Parametric Tools

DOI: $10.7176 / \mathrm{RJFA} / 11-8-09$

Publication date: April $30^{\text {th }} 2020$

\section{Introduction}

From economic perspective, the efficiency of stock markets is the key to optimal allocation of resources. On the investor's dimension, it is necessary to have an efficient stock market to ensure that the investor is involved in a fair game. However, the efficient market hypothesis (EMH) was developed from the Random Walk Theory. The EMH says that the market is efficient at all times implying that share price instantly reflect available information in the market. For that the market is efficient when the market price is only good and correct guide for the share selection. It can also mean that all known information is immediately discounted by all investors and reflected in share prices in the stock market. As such, no one has information edge to make abnormal profit. In the ideal efficient market, every investor knows all available information simultaneously, interprets it similarly, and believes rationally (Cuthbertson and Nitzsche, 2001; Broyle, 2003; Ibenta, 2005; Ezirim, 2005; Bhalla, 2011). It was probably in recognition of this fact that Fama (1965) argued that in a situation where successive bits of new information arise independently across time and investors' conceptions are inconsistent, successive price changes would be independent. Put differently, Stock prices appear to follow a random walk, hence the term random walk hypothesis. Similarly, Samuels and Wilkes (1980) defined an efficient market as one in which prices of traded securities always fully reflect all publicly available information concerning those securities. Furthermore, Samuels and Wilkes (1981) identified necessary conditions for an efficient market to include accurate signals for investors' choices. This implies that today's price which reflects all publicly available information is the best estimate of tomorrow's price (Osaze, 2000).

The price and commodities seemed to follow a random walk of stocks (Brealey and Myers, 2003). This means that market efficiency is consistent with a market in which there are no transactions costs in trading securities; all available information is costless to all market participants, and all participants in the market are rational in decision, suggesting that all agree on the implications of current information for the current price and distributions of future prices of each security (Fama, 1970). According to Rossi and Gunardi (2018) the stock market is an important principle used to measure the efficiency and the correlation between prices and all the information present in a market. Reily (1989) sees an efficient market as one in which security prices adjust rapidly to the infusion of new information and current stock prices fully reflect all available information, including the risks involved. Thus, a stock market is said to be efficient if information is widely and cheaply available to investors such that share prices are fair. A fair share price is one which reflects all available, relevant, and ascertainable information in the market. The efficient market hypothesis may be expressed in a number of alternative ways, and differences between these alternative representations can easily become rather esoteric, technical and subtle (Cuthbertson and Nitzsche, 2001). The implication is that security prices adjust instantly and without bias to any new information released to the market and that expected return is compatible with the risk involved (Afego, 2012). An Efficient Stock market results from the presence of numerous, rational profit maximizing investors, who are actively competing with one another and these resulted to three variants of efficient market hypothesis( weak, semi-strong and strong forms) (Wong and Kwong, 1984; Dimson and Mussavian, Dickinson and Muragu, 1994; 1998; Sharpe et al. 1999; Heman, 2001; Jones and Netter, 2008).

The efficient market theory is a hypothesis that states that share prices reflect all information and consistent alpha generation is impossible. According to the EMH, stocks always trade at their fair value on exchanges, making it impossible for investors to purchase undervalued stocks or sell stocks for inflated prices. Therefore, it should be 
impossible to outperform the overall market through expert stock selection or market timing, i.e. a type of investment or trading strategy. It is the act of moving in and out of a financial market or switching between asset classes based on predictive methods (Segal, 2019) and the only way an investor can obtain higher returns is by purchasing riskier investments. Okpara (2012) believed in reality, the appraised values of a security are based on the assessment made by independent investors. While the assessment made by independent investors depends on the background and information available to him. Financial information is the building blocks from which the analysts construct research analysis that form the bases for their investment recommendations. In such a market, the current price of a security obviously "fully reflects" all available information. But the speed and manner in which the market adjusts to the relevant information on dividend and bonus issues declaration, has been punctuated by untimely release of information and poor behaviour of the authorities. The excruciating influence of timidity that could emanate from insecurity of investors due to the intending insider trading and fall in investors' confidence, deters trading activities and the performance of the market (Manasseh, Asogwa and Agu, 2012). In information efficient market, prices of shares adjusts quickly to new information and enable more informed and efficient investment choices (Osinubi, 2000). In such markets, investors do not care about various trading strategies by fundamentalists, technicalist or chartists to beat the market with the bid of earning abnormal returns. But in the Nigeria capital market, the case is the reverse. In most cases, investors pay extra money to acquire additional information and sometimes go as far as sourcing for insider information on the values of companies listed with the exchange. So far, before certain information is announced, some investors have already traded on the information, causing disparities in available information among market participants.

When a share is overpriced or underpriced as a result of insider information, the level of confidence in the market would be deterred and the returns of the firms would be affected. In turn, the contributions of the firms to all share indexes and the market capitalization would be insignificant (Gao, 2008; Edmans, 2009; Ayadi and Bouri, 2009).. This is because, Investors who are always risk averse could withdraw their money or invest it in other less productive ventures, leaving the market performance gauges in a shamble state (Gagan and Mahendru, 2009; Afego, 2012; George and Oseni, 2012). Stock prices change so that after an adjustment to reflect information like dividends, bonuses, merger and acquisition, earning etc, the time value of money and differential risk equal the market's best forecast of the future price. Therefore, the only factors that can change stock prices are random factors that could not be known in advance (Sergeant and Wallace, 1975). On the relationship between stock market and efficient market hypothesis, studies have revealed mixed results. Some comfirmed weak form efficieny of others found inefficient in the weak form (Emenike ,2008; Bashir et.al, 2009; Agwuegbo et.al, 2010; Okpara, 2010; Sabur and Vitali, 2011; Udoka, 2012;).

The researchers are concerned to validate if Nigeria Stock exchange (NSE) is weak form and to have an empirical stand by investigating the Nigeria Stock Exchange and weak form EMH with annual data and daily data.

\section{Literature Review}

\section{1: Theoretical Literature}

A market is efficient if prices adjust rapidly and, on average, without bias to new info. Thus, there isn't a reason to believe that prices are excessively high or low. So, in an efficient context it is impossible to beat the market. Investors pay a fair price. Based on this theory, an investor's only concern is selecting a particular risk-returns trade-off. However, this model has received a significant amount of attention since its presentation. At first glance, it may be easy to identify a number of deficiencies in the efficient market theory. In fact, studies against the EMH are increasing, particularly with regard to return predictability (Rossi, 2016). Scholars who examine Calendar Anomalies (CAs) have indicated that CAs deny the stock market efficiency (Nasir, Khan and Rossi, 2016). The most common classification system identifies three types of information about past prices, publicly available information, and all information; the Weak Form, the Semi-Strong Form, and the strong Form (Fama, 1970, 1976; Brealey and Myers, 2003; Fisher and Jordan, 2005; Ross, Westerfield, Jaffe and Jordan, 2009; Bhalla, 2011).

\subsection{1: Weak Form and Random Walk EMH}

It holds that present stock market prices reflect all known information with respect to past stock prices, trends and volumes. The weak form of the EMH is summed up in the words of the pseudonymous 'Adam Smith', author of the Money Came: 'Prices have no memory, and yesterday has nothing to do with tomorrow' (Broyle, 2003Brealey and Myers, 2003; Bhalla, 2011). A capital market is said to be weakly efficient or satisfy weak form efficiency if it fully incorporates the information in the past stock prices. Thus the preceding strategy would not be able to generate profit if weak form efficiency holds (Ross, Westerfield, Jaffe and Jordan, 2009).

\subsection{2: Semi-strong form EMH}

This hypothesis states that all publicly available information regarding the prospects of a firm must be reflected already in the stock price. Such information includes, in addition to the past price, fundamental data on the firm's product line, quality of management, statement of financial position, patent held, earning forecast and accounting practices. Again, if investors have access to such information from publicly available sources, one would expect it to be reflected in stock prices (Bodie, Kane, Marcus and Mohanty, 2013). A market is semi strong efficient if 
prices reflect (incorporate) all publicly available information, including information such as published accounting statement for firm as well as historical price information (Broyle, 2003; Brealey and Myers, 2003; Ross, Westerfield, Jaffe and Jordan, 2009).

\subsection{3: Strong form EMH}

A market is strong form efficient if prices reflect all information, private or public (Broyle, 2003; Ross, Westerfield, Jaffe and Jordan, 2009). This version of EMH states that stock prices reflect all information relevant to the firm, even including information available only to company insiders. This variant of the hypothesis is quite extreme. Few would argue with the proposition that corporate officers have access to pertinent information (Brealey and Myers, 2003; Bodie, Kane, Marcus and Mohanty, 2013). It concerned with whether or not certain individuals or group of individuals possess inside information which can be used to make average profit. If the strong form of the efficient capital market hypolthesis holds, then any day is as good as any other day to buy any stock (Broyle, 2003; Bhalla, 2011).

\section{2: Empirical Literature}

The efficiency stance of the Nigerian stock market has in the past and presently led to unending controversy. As such has resulted to plethora of empirical studies on the efficient markets hypothesis globally and Nigeria in particular. Some empirical literature reviewed reveal that actually that past share prices cannot be used as a predicting factor to ascertain future share prices movement in Nigerian stock market, indicating that successive price changes in the market follow a random walk (Olowe, 1999; Bashir, David and Suzanne, 2009; Ajao and Osayuwu, 2012; Udoka, 2012; Efobi, 2012; Ogundina and Omah, 2013). Efforts will be geared to examine some empirical literature to aid the researchers to have a better position on the subject matter. Applying correlation analysis and monthly stock returns data over the period January 1981 and December 1992, Olowe (1999), studied weak form efficiency of the Nigerian stock market to examine if share prices on the Nigerian stock market adjust to historical price information. The study research revealed that the Nigerian market is efficient in weak form.

Employing GARCH and time-varying parameters, to test evolving efficiency for early periods of 1990s and ending of June 2001, Keith and Graham (2005) examined the efficiency of seven African stock markets such as; South Africa, Egypt, morocco, Nigeria, Zimbabwe, Mauritius and Kenya. The test of evolving efficiency found that the Johannesburg stock market was weak form efficient throughout the period under study while Egypt and morocco stock markets tested weak efficient from 1999. Also their findings show that Nigerian market was weak form efficient from early 2001 suggesting that the market follow a random walk. In addition, their result further indicated that Kenya and Zimbabwe stock markets show no tendency towards weak form efficiency, whereas Mauritius market displays a slow tendency to eliminate inefficiency.

With Cointegration and Granger causality tests Augmented Dickey Fuller (ADF-1979, 1981), Phillips-Perron (PP-1988), Dicky-Fuller Generalized Least Square (DF-GLS-1996) and Elliot-Rothenberg-Stock (ERS - 1996) tests, Cooray and Wickramasighe (2007) investigated weak and semi strong form of the efficiency in four South Asian stock markets such as India, Sri Lanka, Pakistan and Bangladesh. After the analysis, Semi-strong form efficiency was not supported as their tests indicate a high degree of interdependence among the South Asian stock markets

Chien-Chong, Jung-De and Chi-Chuan (2010) employed a state-of-the-art panel data stationarity test which incorporates multiple structural breaks to whether the efficient market hypothesis holds in stock markets under different economic development levels using January 1999 to May 2007. After the empirical analysis, it was observed that using general forms of cross-sectional dependence as well as controlling for finite-sample bias, the real stock price series appear to be stationary in 32 developed and 26 developing countries. Again,, real stock price indices are stationary processes that are inconsistent with the efficient market hypothesis.

Ajao and Osayuwu (2012) engaged serial correlation technique and runs test to examine the weak form of efficient market hypothesis in the Nigerian capital market. The study covered all securities traded on the floor of the Nigerian Stock Exchange and the month end value of the All Share Index from 2001 - 2010. The serial correlation technique of data analysis was used to test for independence of successive price movement and the distributive pattern while runs test was used to test for randomness of share price movement. The result of the serial correlation found that the correlation coefficients did not violate the two- standard error test. Again, the BoxLjung statistic revealed that none of the serial correlation coefficients was significant and the Box pierce Qstatistics indicated that the overall significance of the serial correlation test was poor while the result of the distribution pattern shows that stock price movements are approximately normal. On the basis of this finding, they conclude that successive price changes of stocks traded on the floor of the Nigerian Capital Market are independent and random therefore, the Nigerian Capital Market is efficient in the weak-form.

Applying run test and the correlegram/partial autocorrelation function as alternate forms of the research instrument, Okpara (2010) investigated stock market prices and the random walk hypothesis. The results of the three alternate tests revealed that the Nigerian stock market is efficient in the weak form and therefore follows a random walk process. 
Also Okpara (2010) employed GARCH model to further examine the weak form test of the market during the periods of financial deregulation in 1987, public companies privatization in 1988 and internationalization of the Nigerian capital market. The results revealed that the market follows a random walk but further investigation of the reforms showed that the market was inefficient during the financial deregulation, privatization and the internationalization of the capital market while the year 2000 to 2006 recorded persistent volatility clustering suggesting weak form inefficiency. The balanced results suggested that other years were conspicuously and significantly found to exhibit weak form efficiency.

Sabur and Vitali (2011) investigated weak-form efficiency in Africa via multi-approach; unit root, autocorrelation, runs and variance ratio tests on the daily price indices of Egypt, Kenya, Mauritius, Morocco, Nigeria, South Africa and Tunisia over the period 1999-2009. The result obtained indicated the rejection of the random walk hypothesis for all stock markets indices over the whole sample period except South Africa market.

With non-parametric runs test, Afego (2012) x-rayed the weak-form efficient markets hypothesis for the Nigerian stock market by examining the random walks in the monthly index returns over the period 1984-2009. The results found that index returns on the Nigerian Stock Exchange (NSE) display a predictable component, indicating that traders can earn superior returns by employing trading rules. The statistically significant deviations from randomness are also suggestive of sub-optimal allocation of investment capital within the economy. The findings, in general, contradict the weak-form of the efficient markets hypothesis.

Gimba (2012) examined the weak form EMH of the NSE using daily and weekly NSE All Share Index (ASI) and five most traded banks stock of NSE from January 2007 to December, 2009 for the daily and from June 2005 to 2009 for the weekly data. The results revealed that autocorrelation test affirm weak form is inefficient.

Goudarzi (2013) used ADF test and GARCH model to examine market efficiency in India Stock Market through modeling one asset return series. The outputs indicated that underlying series is stationary, mean reverting. Therefore, based on the results the study concluded that the Indian stock market is weak form inefficient.

Employing seven (7) parametric tools; Autocorrelation test, the ADF and P-P unit root tests, Variance Ratio test, the Normality/Random test, the Granger Causality test ARCH-GARCH test and Regression test, Ogbulu (2016) investigated the efficiency level of Nigerian Stock Exchange (NSE) across different data estimation intervals (daily, weekly, monthly and quarterly aggregate stock price data using the NSE all share index series from 1999 to 2013) with reference to the weak form variant of EMH. The result found that on balance the NSE is weak form inefficient when daily, weekly, monthly and quarterly prices are examined irrespective of the estimation interval and the parametric test employed in the tests.

Adebanjo, Awonusi and Eseyin (2018) looked at the weak- form efficiency of the Nigerian stock market. Employing Partial autocorrelation (PACF) test to test for independence of stock prices, the runs test and the distribution patterns to test for randomness of stock prices and the one-sample Kolmogorov Smirnov test to examine the observable trend in the pattern of stock price movements. After the analysis, the movements of stock prices in the stock market were observed to be independent. The movements of stock prices in the stock market were not random. Also was an observable trend in the pattern of stock prices movement in the stock market. The result of the partial auto correlation test showed that the movements of the stock prices are independent. Again the result of the runs test and the distribution patterns also shows that the movements of stock prices were not completely random.

\section{Data and Tools}

This study adopted various econometric tools; ADF unit root test, Autocorrelation test, Pairwise Granger Causality test, Regression test, Normality/Random Walk test and ARCH-GARCH models The study employed two intervals of All Share Index (ASI) with daily data from January 02, 2014 to May 20, 2019 (1333 observations) and annual data from 1985 to 2018 (34 observations) collected from the Nigeria Stock Market fact books.

\section{Empirical Results}

This study commenced with the examination of the distribution of daily and annual data with descriptive statistics shown below; 
Table 1: Descriptive Statistics

\begin{tabular}{|l|c|c|}
\hline & DAILY_ASI & ANNUAL_ASI \\
\hline Mean & 32982.60 & 15205.32 \\
\hline Median & 32203.62 & 11550.40 \\
\hline Maximum & 45092.83 & 45908.88 \\
\hline Minimum & 22456.32 & 127.3000 \\
\hline Std. Dev. & 5642.280 & 13992.35 \\
\hline Skewness & 0.250139 & 0.594573 \\
\hline Kurtosis & 1.872985 & 2.254315 \\
\hline Jarque-Bera & 84.44774 & 2.790994 \\
\hline Probability & 0.000000 & 0.247710 \\
\hline Sum & 43965802 & 516980.8 \\
\hline Sum Sq. Dev. & $4.24 \mathrm{E}+10$ & $6.46 \mathrm{E}+09$ \\
\hline Observations & 1333 & 34 \\
\hline
\end{tabular}

Authors' computation output using E-view 10.

Table 1 above summarized the distribution of daily and annual all share index (ASI). The table revealed that daily data Jarque Bera recorded coefficient of 84.44774 with probability value of 0.000000 suggesting an abnormal distribution, while annual data Jarque Bera has coefficient of 2.790994 with probability value of 0.247710 indicating a normal distribution.

Next is unit root test, which in macroeconomic analysis is a popular test of stationarity of time series data because of the dependent nature of most economic variables. This study use ADF unit root as shown below;

Table 2: Unit root at Level

Null Hypothesis: DAILY_ASI has a unit root

sExogenous: Constant

Lag Length: 1 (Automatic - based on SIC, maxlag=22)

\begin{tabular}{|c|c|c|c|}
\hline & & t-Statistic & Prob.* \\
\hline \multicolumn{2}{|c|}{ Augmented Dickey-Fuller test statisti } & -1.817730 & 0.3721 \\
\hline \multirow[t]{3}{*}{ Test critical values: } & $1 \%$ level & -3.435052 & \\
\hline & $5 \%$ level & -2.863504 & \\
\hline & $10 \%$ level & -2.567865 & \\
\hline \multicolumn{4}{|c|}{ Null Hypothesis: ANNUAL_ASI has a unit root } \\
\hline \multicolumn{4}{|l|}{ Exogenous: Constant } \\
\hline \multicolumn{4}{|c|}{ Lag Length: 0 (Automatic - based on SIC, maxlag=8) } \\
\hline & & t-Statistic & Prob.* \\
\hline \multicolumn{2}{|c|}{ Augmented Dickey-Fuller test statistic } & -1.235789 & 0.6469 \\
\hline \multirow[t]{3}{*}{ Test critical values: } & $1 \%$ level & -3.646342 & \\
\hline & $5 \%$ level & -2.954021 & \\
\hline & $10 \%$ level & -2.615817 & \\
\hline
\end{tabular}

Authors' computation output using E-view 10.

Table 3: Unit at $1^{\text {st }}$ Difference

Null Hypothesis: D(DAILY_ASI) has a unit root

Exogenous: Constant

Lag Length: 0 (Automatic - based on SIC, maxlag=22)

\begin{tabular}{|c|c|c|c|}
\hline & & t-Statistic & Prob.* \\
\hline \multicolumn{2}{|c|}{ Augmented Dickey-Fuller test statistic } & -30.12417 & 0.0000 \\
\hline \multirow[t]{3}{*}{ Test critical values: } & $1 \%$ level & -3.435052 & \\
\hline & $5 \%$ level & -2.863504 & \\
\hline & $10 \%$ level & -2.567865 & \\
\hline \multicolumn{4}{|c|}{ Null Hypothesis: D(ANNUAL_ASI) has a unit root } \\
\hline \multicolumn{4}{|l|}{ Exogenous: Constant } \\
\hline \multicolumn{4}{|c|}{ Lag Length: 1 (Automatic - based on SIC, maxlag=8) } \\
\hline & & t-Statistic & Prob.* \\
\hline \multicolumn{2}{|c|}{ Augmented Dickey-Fuller test statistic } & -5.970826 & 0.0000 \\
\hline \multirow[t]{3}{*}{ Test critical values: } & $1 \%$ level & -3.661661 & \\
\hline & $5 \%$ level & -2.960411 & \\
\hline & $10 \%$ level & -2.619160 & \\
\hline
\end{tabular}

Authors' computation output using E-view 10. 
Tables 2 and 3 depict the results of unit test for daily ASI and annual ASI. The results revealed that both daily and annual data are not stationary at level, rather are both differenced once to be stationary at 5\%. Therefore, since they level series are not significant, indicating predictability in all level series. The results affirm the weak form inefficiency.

The researchers then proceeded to Autocorrelation test. The autocorrelation is special correlation test that examines the relationship between successive values of the same variable, not actually between two or more variables. The test is depicted below;

Table 4: Autocorrelation Test

\section{Daily ASI}

\begin{tabular}{|c|c|c|c|c|c|c|}
\hline Autocorrelation & Partial Correlation & & $\mathrm{AC}$ & PAC & Q-Stat & Prob \\
\hline$* * * * * * *$ & $* * * * * * *$ & 1 & 0.997 & 0.997 & 1327.3 & 0.000 \\
\hline |******* & $* \mid$ & 2 & 0.993 & -0.148 & 2644.4 & 0.000 \\
\hline |******* & & 3 & 0.988 & -0.026 & 3950.5 & 0.000 \\
\hline |******* & & 4 & 0.983 & -0.013 & 5245.4 & 0.000 \\
\hline |******* & & 5 & 0.979 & -0.028 & 6528.6 & 0.000 \\
\hline |******* & & 6 & 0.974 & 0.000 & 7800.0 & 0.000 \\
\hline |******* & & 7 & 0.969 & 0.034 & 9060.2 & 0.000 \\
\hline$* * * * * * *$ & & 8 & 0.965 & 0.024 & 10310. & 0.000 \\
\hline |******* & & 9 & 0.960 & 0.018 & 11549. & 0.000 \\
\hline$* * * * * * *$ & & 10 & 0.956 & -0.010 & 12779. & 0.000 \\
\hline |******* & & 11 & 0.952 & 0.015 & 13999. & 0.000 \\
\hline$* * * * * * *$ & & 12 & 0.948 & 0.025 & 15210. & 0.000 \\
\hline |******* & & 13 & 0.944 & -0.013 & 16412. & 0.000 \\
\hline |******* & & 14 & 0.941 & 0.034 & 17606. & 0.000 \\
\hline |******* & & 15 & 0.937 & -0.014 & 18791. & 0.000 \\
\hline |******** & & 16 & 0.933 & -0.016 & 19967. & 0.000 \\
\hline | $* * * * * * *$ & & 17 & 0.929 & -0.029 & 21134. & 0.000 \\
\hline$* * * * * * *$ & & 18 & 0.925 & 0.025 & 22293. & 0.000 \\
\hline |******** & & 19 & 0.921 & -0.024 & 23442 . & 0.000 \\
\hline$* * * * * * *$ & & 20 & 0.917 & -0.014 & 24582 . & 0.000 \\
\hline |******** & & 21 & 0.913 & 0.005 & 25712 & 0.000 \\
\hline |******** & & 22 & 0.908 & -0.045 & 26832. & 0.000 \\
\hline$* * * * * * *$ & & 23 & 0.904 & -0.013 & 27942. & 0.000 \\
\hline$|* * * * * *|$ & & 24 & 0.900 & 0.035 & 29042 . & 0.000 \\
\hline$|* * * * * *|$ & & 25 & 0.895 & -0.031 & 30132 . & 0.000 \\
\hline$|* * * * * *|$ & & 26 & 0.890 & -0.003 & 31212 . & 0.000 \\
\hline$|* * * * * *|$ & & 27 & 0.886 & -0.034 & 32281. & 0.000 \\
\hline$|* * * * * *|$ & & 28 & 0.881 & -0.049 & 33339. & 0.000 \\
\hline$|* * * * * *|$ & & 29 & 0.875 & -0.023 & 34384 . & 0.000 \\
\hline$|* * * * * *|$ & & 30 & 0.870 & 0.023 & 35419. & 0.000 \\
\hline$|* * * * * *|$ & & 31 & 0.865 & 0.014 & 36441. & 0.000 \\
\hline$|* * * * * *|$ & i & 32 & 0.860 & -0.011 & 37453. & 0.000 \\
\hline$|* * * * * *|$ & 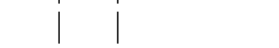 & 33 & 0.855 & 0.003 & 38454 & 0.000 \\
\hline$|* * * * * *|$ & 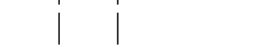 & 34 & 0.850 & 0.041 & 39444. & 0.000 \\
\hline$|* * * * * *|$ & & 35 & 0.846 & 0.018 & 40425 . & 0.000 \\
\hline$|* * * * * *|$ & | & 36 & 0.842 & 0.009 & 41397. & 0.000 \\
\hline
\end{tabular}


Annual ASI

\begin{tabular}{|c|c|c|c|c|c|c|}
\hline Autocorrelation & Partial Correlation & & $\mathrm{AC}$ & PAC & Q-Stat & Prob \\
\hline$|* * * * * *|$ & $|* * * * * *|$ & 1 & 0.849 & 0.849 & 26.713 & 0.000 \\
\hline$|* * * * *|$ & *|. & 2 & 0.689 & -0.110 & 44.895 & 0.000 \\
\hline . $* * * * *$ &.$\left.\right|^{* *}$ & 3 & 0.637 & 0.293 & 60.921 & 0.000 \\
\hline. $\mid * * * *$ & * $*$ & 4 & 0.568 & -0.141 & 74.068 & 0.000 \\
\hline $\mid * * * *$ &.$\left.\right|^{*}$ & 5 & 0.494 & 0.084 & 84.365 & 0.000 \\
\hline $\mid * * *$ & .1. & 6 & 0.457 & 0.027 & 93.480 & 0.000 \\
\hline $\mid * * *$ & *|. & 7 & 0.385 & -0.143 & 100.18 & 0.000 \\
\hline$\left.\right|^{* *}$ &.$* 1$. & 8 & 0.280 & -0.089 & 103.87 & 0.000 \\
\hline$\left.\right|^{* *}$ & .1. & 9 & 0.224 & 0.038 & 106.32 & 0.000 \\
\hline$\left.\right|^{*}$ & .1. & 10 & 0.199 & 0.018 & 108.35 & 0.000 \\
\hline.$\left.\right|^{*}$ & $* * \mid$ & 11 & 0.087 & -0.309 & 108.74 & 0.000 \\
\hline .1. & $* 1$. & 12 & -0.041 & -0.077 & 108.84 & 0.000 \\
\hline$*$ & $*$. & 13 & -0.126 & -0.139 & 109.76 & 0.000 \\
\hline$* 1$. & .1. & 14 & -0.203 & -0.028 & 112.29 & 0.000 \\
\hline$* *||$. & $*$. & 15 & -0.281 & -0.108 & 117.37 & 0.000 \\
\hline$* * \mid$ & .1. & 16 & -0.323 & -0.017 & 124.44 & 0.000 \\
\hline
\end{tabular}

\section{Authors' computation output using E-view 10.}

Table 4 shows the autocorrelation test for daily and annual data. Both revealed that the individual autocorrelation (AC) at different lags from 1-36 and the associated probability values suggest that successive of the prices are significant from 1-36 for daily ASI and 1-16 for annual ASI. That means they are not weak efficient.

Next is Granger Causality test. This is useful for testing the short run direction of causality among variables. Here, Pairwise Granger Causality test is used as revealed below;

Table 5: Daily ASI

\begin{tabular}{|c|c|c|c|}
\hline \multicolumn{4}{|l|}{ Pairwise Granger Causality Tests } \\
\hline \multicolumn{4}{|l|}{ Sample: $1 / 02 / 2014$ 5/20/2019 } \\
\hline \multicolumn{4}{|l|}{ Lags: 1} \\
\hline Null Hypothesis: & Obs & F-Statistic & Prob. \\
\hline DAILY_ASI does not Granger Cause DAIL_Y ASI 1 & 1332 & 11359.7 & 0.0000 \\
\hline \begin{tabular}{|lll} 
DAIL Y ASI 1 does not Granger Cause DAILY ASI & $\bar{A}$
\end{tabular} & & 0.44509 & 0.5048 \\
\hline
\end{tabular}

\section{Annual ASI}

Pairwise Granger Causality Tests

Lags: 1

\begin{tabular}{|l|c|c|r|}
\hline Null Hypothesis: & Obs & F-Statistic & Prob. \\
\hline ANNUAL_ASI does not Granger Cause ANNUAL_ASI_1_ & 33 & 0.13754 & 0.7133 \\
\hline ANNUAL_ASI_1_does not Granger Cause ANNUAL_ASI & & 0.15033 & 0.7010 \\
\hline
\end{tabular}

ANNUAL_ASI _ 1_ does not Granger Cause ANNUAL_ASI

\section{Authors' computation output using E-view 10.}

Granger Causality tests for daily and annual price series showed mixed output. For daily ASI, there is causality recorded; though a unidirectional causality whereas no causality is found for annual ASI. The absence of causality for annual ASI suggests weak form efficiency.

Then the researchers moved to checking the relationship between the successive variables using Ordinary Least Square (OLS) Model as shown below; 
Table 6: Ordinary Least Square Regression

Dependent Variable: DAILY_ASI

Method: Least Squares

Date: 04/16/20 Time: 08:09

Sample: 1/02/2014 5/20/2019

Included observations: 1333

\begin{tabular}{|l|r|r|r|r|}
\hline \multicolumn{1}{|c|}{ Variable } & Coefficient & Std. Error & t-Statistic & Prob. \\
\hline DAIL_Y_ASI 1 & 0.968714 & 0.005353 & 180.9732 & 0.0000 \\
\hline C & 1061.861 & 179.0101 & 5.931851 & 0.0000 \\
\hline R-squared & 0.960947 & Mean dependent var & 32982.60 \\
\hline Adjusted R-squared & 0.960918 & S.D. dependent var & 5642.280 \\
\hline S.E. of regression & 1115.430 & Akaike info criterion & 16.87337 \\
\hline Sum squared resid & $1.66 \mathrm{E}+09$ & Schwarz criterion & 16.88116 \\
\hline Log likelihood & -11244.10 & Hannan-Quinn criter. & 16.87629 \\
\hline F-statistic & 32751.28 & Durbin-Watson stat & 0.962995 \\
\hline Prob(F-statistic) & 0.000000 & \multicolumn{2}{|l}{}
\end{tabular}

Dependent Variable: ANNUAL_ASI

Method: Least Squares

Included observations: 34 after adjustments

\begin{tabular}{|c|c|c|c|c|}
\hline Variable & Coefficient & Std. Error & t-Statistic & Prob. \\
\hline ANNUAL ASI 1 & 0.999701 & 0.000271 & 3694.234 & 0.0000 \\
\hline $\mathrm{C}$ & 8.294537 & 5.553983 & 1.493439 & 0.1451 \\
\hline R-squared & 0.999998 & \multicolumn{2}{|c|}{ Mean dependent var } & 15205.32 \\
\hline Adjusted R-squared & 0.999998 & \multicolumn{2}{|c|}{ S.D. dependent var } & 13992.35 \\
\hline S.E. of regression & 21.75818 & \multicolumn{2}{|c|}{ Akaike info criterion } & 9.054880 \\
\hline Sum squared resid & 15149.40 & \multicolumn{2}{|c|}{ Schwarz criterion } & 9.144665 \\
\hline Log likelihood & -151.9330 & \multicolumn{2}{|c|}{ Hannan-Quinn criter. } & 9.085499 \\
\hline F-statistic & 13647362 & \multicolumn{2}{|c|}{ Durbin-Watson stat } & 1.077120 \\
\hline
\end{tabular}

Prob(F-statistic)

\section{Authors' computation output using E-view 10.}

Table 6 of the OLS above shows a significant relationship between the successive variables (prices regressed on their lagged value) for both daily and annual price series. That implies, historical prices can be used to predict current and future prices in the stock market. The outputs validate weak form inefficiency with both daily and annual ASI.

Another text test is check the distribution/randomness of price series as shown below; 
Table 7: Normality Test

DAILY ASI

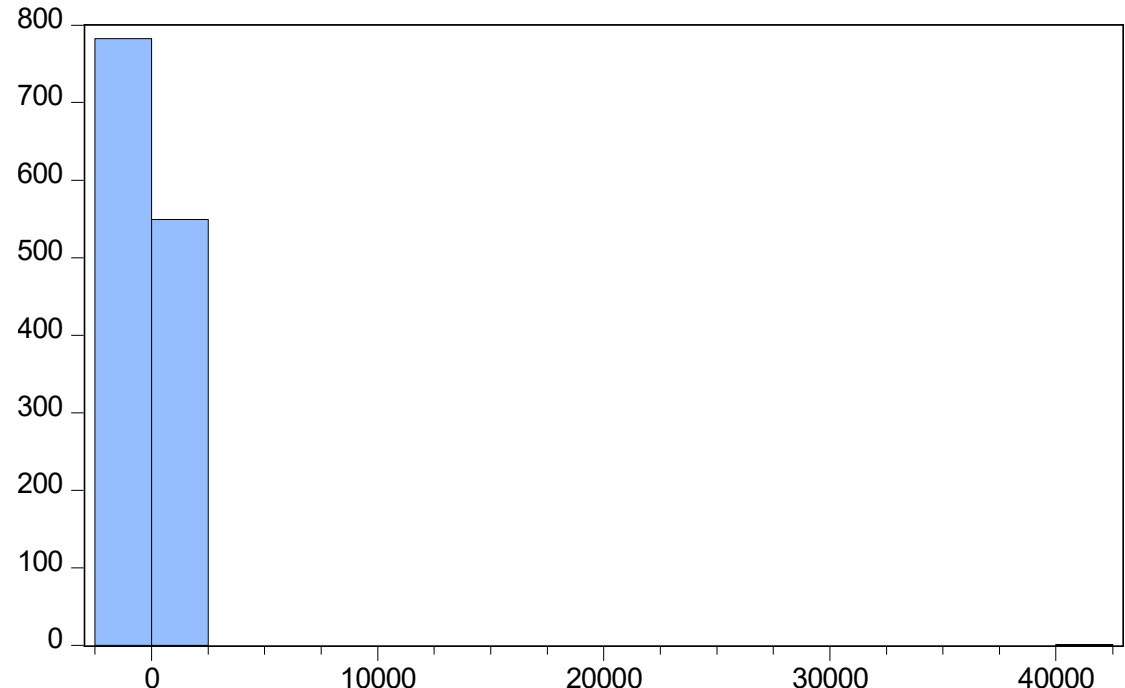

ANNUAL ASI

28

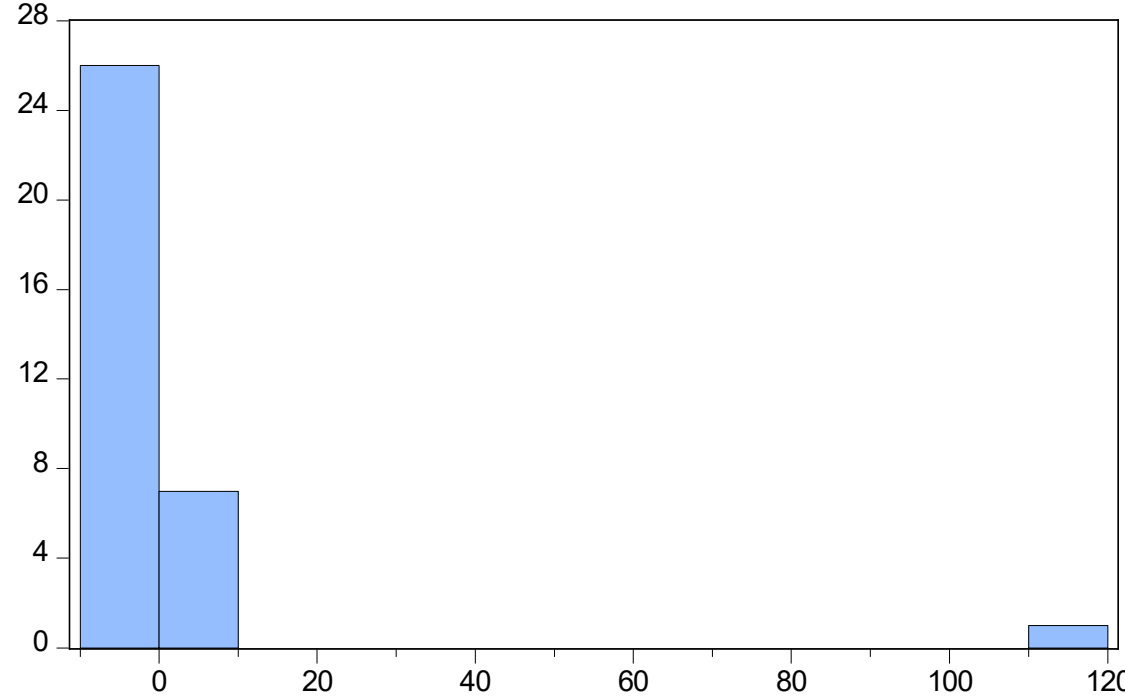

Series: Residuals

Sample 1/02/20145/20/2019

Observations 1333

Mean

$-9.21 \mathrm{e}-12$

Median $-54.33268$

Maximum

40166.63

Minimum

$-359.2886$

Std. Dev.

1115.011

Skewness

35.10783

Kurtosis

1265.221

Jarque-Bera

88762946

Probability

0.000000

\section{Series: Residuals \\ Sample 1/02/2014 2/19/2014 \\ Observations 34 \\ Mean \\ $-1.35 e-12$ \\ Median \\ $-4.314925$ \\ Maximum \\ 119.0055 \\ Minimum \\ $-8.245506$ \\ Std. Dev. \\ 21.42598 \\ Skewness \\ 5.250741 \\ Kurtosis \\ 29.72129 \\ Jarque-Bera \\ 1167.771 \\ Probability 0.000000}

\section{Authors' computation output using E-view 10.}

Table 7 above for daily and annual ASI show Jarque-Bera coefficients are significant suggesting abnormal distribution. This abnormal distribution indicates that price series do not follow random walk. The market is therefore inefficient in weak form.

Finally is the ARCH-GARCH developed by Engle 1982 and used to capture the effect of serial correlation of volatility in time series data. It expresses conditional variance as distributed lag of past squared. This is showed below. 
Table 8: ARCH-GARCH Test

Dependent Variable: DAILY ASI

Method: ML ARCH - Normal distribution (BFGS / Marquardt steps)

\begin{tabular}{|c|c|c|c|c|}
\hline \multicolumn{5}{|c|}{$\mathrm{GARCH}=\mathrm{C}(3)+\mathrm{C}(4) * \mathrm{RESID}(-1)^{\wedge} 2+\mathrm{C}(5)^{*} \mathrm{GARCH}(-1)$} \\
\hline Variable & Coefficient & Std. Error & z-Statistic & Prob. \\
\hline DAIL_Y_ASI 1 & 1.000318 & $5.01 \mathrm{E}-06$ & 199490.4 & 0.0000 \\
\hline $\mathrm{C}$ & -10.80190 & 0.260922 & -41.39895 & 0.0000 \\
\hline \multicolumn{5}{|c|}{ Variance Equation } \\
\hline $\mathrm{C}$ & 4.663233 & 1.206180 & 3.866117 & 0.0001 \\
\hline $\operatorname{RESID}(-1)^{\wedge} 2$ & -0.069270 & 0.028074 & -2.467429 & 0.0136 \\
\hline GARCH(-1) & 0.516412 & 0.112157 & 4.604350 & 0.0000 \\
\hline R-squared & 0.959894 & \multicolumn{2}{|c|}{ Mean dependent var } & 32982.60 \\
\hline Adjusted R-squared & 0.959864 & \multicolumn{2}{|c|}{ S.D. dependent var } & 5642.280 \\
\hline S.E. of regression & 1130.375 & \multicolumn{2}{|c|}{ Akaike info criterion } & 4.476674 \\
\hline Sum squared resid & $1.70 \mathrm{E}+09$ & \multicolumn{2}{|c|}{ Schwarz criterion } & 4.496161 \\
\hline Log likelihood & -2978.703 & \multicolumn{2}{|c|}{ Hannan-Quinn criter. } & 4.483976 \\
\hline Durbin-Watson stat & 1.000113 & & & \\
\hline
\end{tabular}

Dependent Variable: ANNUAL_ASI

Method: ML ARCH - Normal distribution (BFGS / Marquardt steps)

$\mathrm{GARCH}=\mathrm{C}(3)+\mathrm{C}(4) * \mathrm{RESID}(-1)^{\wedge} 2+\mathrm{C}(5) * \mathrm{GARCH}(-1)$

\begin{tabular}{|c|r|r|r|r|}
\hline Variable & Coefficient & Std. Error & Z-Statistic & Prob. \\
\hline ANNUAL_ASI 1 & 0.999972 & 0.002680 & 373.0871 & 0.0000 \\
\hline C & 0.055972 & 56.39380 & 0.000993 & 0.9992 \\
\hline C & 85.79159 & 46.71339 & 1.836552 & 0.0663 \\
\hline RESID(-1)^2 & -0.069334 & 0.048208 & -1.438225 & 0.1504 \\
\hline GARCH(-1) & 0.488564 & 0.191065 & 2.557055 & 0.0106 \\
\hline R-squared & 0.999997 & Mean dependent var & 15205.32 \\
\hline Adjusted R-squared & 0.999997 & S.D. dependent var & 13992.35 \\
\hline S.E. of regression & 22.50055 & Akaike info criterion & 7.224405 \\
\hline Sum squared resid & 16200.79 & Schwarz criterion & 7.448870 \\
\hline Log likelihood & -117.8149 & Hannan-Quinn criter. & 7.300954 \\
\hline Durbin-Watson stat & 1.000274 & \multicolumn{3}{l}{}
\end{tabular}

Authors' computation output using E-view 10.

Table 8 above revealed that GARCH output for daily and annual ASI coefficients of variance equations are statistically significant implying weak form inefficiency and presence of volatility clustering.

\section{Conclusion and Recommendation}

This study; Nigerian Stock Market and Weak Form Efficiency found for daily and annual all share index as follows: a significant relationship between the price series and their lagged values; coefficient of variance equations are statistically significant; all successive lags of autocorrelation are significant; price series do not follow a random walk or are abnormally distributed; level series not significant and causality is found in daily price series with no causality found in the annual price series. The finding in this study in balance affirmed that the Nigeria Stock Exchange is not efficient in weak form, by extension is inefficient in any form. The observations in this study corroborate the findings of Emenike (2010); Gimba (2012); Afego (2012); Goudarzi (2013) and Ogbulu (2016) but contradict findings of Ajao and Osayuwu (2012); Okpara (2010); Olowe (1999) and Keith and Graham (2005).

Consequently, the researchers suggest to the supervisory and regulatory authorities to promulgate laws that will strengthen the Nigerian Stock Market. This is because the depth of a stock market determines the extent of growth and development of any nation.

\section{Reference}

Adebanjo, J.F., Awonusi, F. \& Eseyin, O. (2018). The weak form market efficiency and the Nigerian stock exchange. Afro Asian Journal of Social Science, 9(4). 1-17.

Adelegan. O. J. (2009), Price reactions to dividend announcements on the Nigerian stock market.

$A E R C$ Research Paper 188. Nairobi. 
Afego, P. (2011). Stock price response to earnings announcements: evidence from Nigeria. Available at SSRN:http://ssrn.com/abstract $=1768762$. Retrieved 10/4/2020

Afego, P. (2012). Weak form efficiency of the nigerian stock market: An empirical analysis.International Journal of Economics and Financial Issues. 2(3), 340-347.

Agwuegbo, S.O.N., Adewole, A.P. \& Maduegbuna, A.N. (2010). A random walk model for stock market prices. Journal of Mathematics and Statistics. 6(3), 342-346.

Ajao, G \& Osayuwu, R. (2012). Testing the weak form of efficient market hypothesis in Nigerian capital market. Accounting and Finance Research, 1(1)

Ayadi, S. \& Bouri, A. (2009). Intervening parties' behaviours and its impact on the financial market functioning. International Research Journal of Finance and Economics. 31, $101-$

115.

Bashir, T., David, P. \& Suzanne, F. (2009). An empirical investigation of the weak-form of the efficient market hypothesis for the Nigerian stock exchange. African Finance Journal. $\quad 11(2), 1-27$.

Bhalla, V.K. (2011). Investment management: Security analysis and portfolio management. New Delhi: S. Chad and Company Ltd.

Bodie, Z., Kane, A., Marcus, A.J. \& Mohanty, P. (2013). Investment ( ${ }^{\text {th }}$ editon). New Delhi: McGraw Hill Education.

Brealey, R.A. \& Myers, S.C. (2003). Principles of corporate finance. New Delhi: McGraw Hill.

Broyles, J. (2003). Financial management and real options. England: John Wiley \& Son Ltd.

Chien-Chong, L., Jung-De, L, \& Chi-Chuan, L. (2010). Stock prices and the efficient market hypothesis: Evidence from a panel stationary test with structural breaks. Japan and the World Economy,(22)1, 49-58.

Cooray, V \& Wickramasighe, G. (2007). The efficiency of emerging stock markets: Empirical evidence from the South Asian region. Journal of Developing Areas. 41(1), 171-183.

Cuthbertson, K. \& Nitzsche, K. (2005). Investments: Spot and derivatives market. New York: JohnWilley and Sons Ltd.

Dickinson, J. P. \& Muragu, K. (1994). Market efficiency in developing countries: A case study of the Nairobi stock exchange. Journal of Business Finance and Accounting, 21(1), 133-150.

Dimson, E. \& Mussavian, M. (1998). A brief of history of market efficiency. European Financial Management, 4(1), 91-193.

Edmans, A.(2009). Blockholder trading, market efficiency and managerial myopia. The Journal of Finance, 64(.6), $2481-2513$.

Efobi .U.R. (2010). The efficient market hypothesis: Realities from the Nigerian stock market. Global Journal of Finance and Management, 2(2), 321-331.

Emenike, K.O. (2008). Empirical test for weak form efficient market hypothesis of the Nigerian stock exchange. Social Science Research Network (SSRN). Working Paper Series.

Ezirim, B.C. (2005). Finance dynamics: Principles, techniques and approaches. Portharcourt: Markowitz Centre for Research and Development.

Fama, E. (1965). The behaviour of stock market prices. Journal of Business, 38, January edition, 34-49.

Fama, E.F. (1970). Efficient capital markets: A review of theory and empirical work. Journal of Finance, 25(1), 83-417.

Fama, E. F. (1976). Reply to efficient capital markets: Comments. Journal of Finance, 31(1), 143-145

Fisher, D.E. \& Jordan, R.J.(2005). Security analysis and portfolio management. Delhi: Pearson Education.

Gagan. D.S \& Mahendru. M. (2009). Efficiency hypothesis of the stock markets: A case of Indian securities. International Journal of Business and Management. Available at SSRN: http://ssrn.com/abstract=1827522. Retrieved 01/3/2020

Gao, P. (2008). Keynesian beauty contest, accounting disclosure and market efficiency. Journal of Accounting Research, 46(4), $785-807$.

George, E.O. \& Oseni, J.E. (2012). The influence of information asymmetry on equity pricing: A theoretical perspective. American Journal of Scientific Research, 65, 42-50.

Gimba, V.K. (2012). Testing the weak form efficiency market hypothesis: Evidence from Nigeria stock market. CBN Journal of Applied Statistics, 3(1), 117-136.

Goudarzi,H. (2013). Volatility mean reversion and stock market efficiency. Asian Economic and Financial Review, 3(13), 1681-1692.

Heman, S.C. (2001). Security management and the validity of portfolio market theories, An MBA. Project submitted to the Department of Business Administration, University of Benin, Nigeria.

Ibenta, S.N. (2005). Investment analysis and financial management strategy. Enugu: Institute of Development Studies.

Jones, S. L. \& Netter, J. M. (2008). Efficient capital markets. The concise encyclopedia of economics. Library of economics and liberty. Http://www.econlib.org/library/Enc/EfficientCapitalMarkets.html. Retrieved $20 / 2 / 2020$ 
Keith. J \& Graham. S (2005). The changing efficiency of African stock markets. South African Journal of Economics 73,1

Manasseh, O.C, Asogwa, F.O \& Agu, D.O (2012). The causality effect of stock market development,financial sector reforms and economic growth in Nigeria; The Applicationof Vector Autoregressive (VAR) and Vector Error Correction Model (VECM). A Paper presented at the Global Development Finance Conference. Crystal Towers, Century City, Cape Town, South Africa.

Nasir, M.A., Khan, K. \& Rossi M. (2016). The calendar anomalies on performance and volatility of stock market: The effects of Ramadan on Karachi Stock exchange .https://www.researchgate.net/publication/322984494. Accessed, Apr 132020.

Ogbulu, O.M. (2016). Weak-form market efficiency, estimation interval and the Nigerian Stock Exchange: Empirical evidence. International Journal of Economic and Business, $\quad$ 5(1), 84-116.

Ogundina, J. A \& Omah, I. (2013). Test of capital market efficiency theory in the Nigerian capital market. Research Journal of Finance and Accounting. 4(1)

Okpara, G. C. (2010a). Stock market prices and the random walk hypothesis: Further evidence from Nigeria. Journal of Economics and International Finance, 2(3), 49-57.

Okpara, G. C. (2010b). Analysis of weak form efficiency on the Nigerian stock Market: Further evidence from GARCH model. The International Journal of Applied Economics and Finance, 4(2), 62-66.

Okpara, G.C. (2012). Fundamentals of corporate financial management. Uyo: Donil Prints Ltd

Olowe, A. R. (1999). Weak form efficiency of the Nigeria stock market: Further evidence. African Development Review. 11, 54

Oludoyi, S. B. (1998). Capital market efficiency and the effects of earning announcements on share prices in Nigeria. PhD. Thesis, University of Ibadan, unpublished.

Osaze, B.E. (2000). Nigerian Capital Market in the African and Global Financial System, Benin City: Bofic Consulting Group Limited.

Osinubi, T. S. (2000). Does stock market promote economic growth in Nigeria? http://sta.uwi.edu/conferences/financeconference. Rtrieved 3/2/2020

Otaniyi, O. \& Makina, D. (2010). Price behaviour of new share listings in Nigeria. International Business \& Economics Research Journal, .9,4.

Reily, F.K. (1989). Investment analysis and portfolio management, Hinsdale, Illinois: Dryden press

Ross, S.A., Westerfield, R.W., Jaffe, J. \& Jordan, B.D. (2009). Modern financial management ( $8^{\text {th }}$ edition). New Delhi: McGraw Hill.

Rossi, M. (2016). The capital asset pricing model: A critical literature review. Global Business and Economics Review, 18(5), 604-617.

Rossi,M. \& Guardi, A. (2018). Efficient market hypothesis and stock market anomalities: Empirical evidence in four European countries. The Journal of Applied Business Research, 34(1), 183-192.

Sabur, M \& Vitali, F. (2011). Stock market efficiency in Africa, Evidence from random walk hypothesis. www. Googlescholar.com. Retrieved 4/3/2020

Samuels, J.M \& R. Wilkes (1981).Management of Company Finance, Lagos: Thomas Nelson

Segal, T. (2019). Market timing. www.investopia.org. Retrieved 0n 09/04/2020

Sergeant, T. J. \& Wallace, N. (1975). Rational expectations, the optimal monetary instrument, and the optimal money supply rule. Journal of Political Economy, 83, 241-54.

Sharpe, W. F., Alexander, G. J. \& Bailey, J. V. (1999). Investments. (6th Edition). Upper Saddle River: PrenticeHall, Inc.

Udoka, C. O. (2012). Weak-form market efficiency: Dynamic effects of information on the Nigerian stock market. Interdisciplinary journal of contemporary research in business, $4,7$.

Wong K. \& Kwong K, (1984). The behaviour of Hong Kong stock prices. Applied Economics. 16, 905-917. 